\title{
STUDY TO DEVELOP ESSENTIAL PLANNING DATA FOR CONTERMINOUS U.S. AERIAL RADIOMETRIC SURVEYS
}

TEXAS INSTRUMENTS INCORPORATED

Dallas, Texas

March 1978

WORK PERFORMED UNDER

BENDIX FIELD ENGINEERING CORPORATION

GRAND JUNCTION OPERATIONS, GRAND JUNCTION, COLORADO Subcontract No. 78-104-L and Bendix Contract No. EY-76-C-13-1664

PREPARED FOR

U.S. DEPARTMENT OF ENERGY

Grand Junction, Colorado 81501 


\section{LEGAL NOTICE}

This report was prepared as an account of work sponsored by the United States Government. Neither the United States nor the United States Department of Energy nor any of their employees, nor any of their contractors, subcontractors, or their employees, makes any warranty, express or implied, or assumes any legal liability or responsibility for the accuracy, completeness or usefulness of any information, apparatus, product or process disclosed, or represents that its use would not infringe privately owned rights. 
STUDY TO DEVELOP ESSENTIAL PLANNING DATA

FOR CONTERMINOUS U.S. AERIAL RADIOMETRIC SURVEYS

TEXAS INSTRUMENTS INCORPORATED

Dallas, Texas

March 1978

Work Performed Under

BENDIX FIELD ENGINEERING CORPORATION

Grand Junction Operations

Grand Junction, Colorado

Subcontract No. 78-104-L and

Bendix Contract No. EY-76-C-13-1664

Prepared for

U.S. DEPARTMENT OF ENERGY

Grand Junction, Colorado 81501 
Data essential to planning aerial radionetric surveys for uranium are presented for each 1:250,000-scale NTMS quadrangle of the conterminous United States on microfiche and in digital form on magnetic tape. Planning parameters include

- Quadrangle priority based on geology and known uranium occurrences

- Anticipated relative counting rates based on general soil moisture content and lithology

- Terrain evaluation for aircraft selection

- Estimates of average viable flying hours per month based on climatology

- A selection of airports suitable for DC-3 aircraft operations

This study was done by Texas Instruments under Bendix Field Engineering Subcontract No. 78-104-L as part of the U.S. Department of Energy National Uranium Resource Evaluation Program. 


\section{TABLE OF CONTENTS}

Section

ABSTRACT

I

INTRODUCTION

A. GENERAL

B. DATA FORMATS

1. Microfiche Listings

2. Magnetic Tape

II

PLANNING PARAMETERS

A. GEOLOGIC PRIORITY

1. General

2. Method of Analysis

3. Quadrangle Priority Groups

B. ANTICIPATED RELATIVE COUNTING RATE 8

1. General 8

2. Method of Analysis 8

3. Combined Moisture and Lithology Factors 10

C. TERRAIN FACTORS IN AIRCRAFT SELECTION 10

$\begin{array}{ll}1 . \text { General } & 10\end{array}$

2. Method of Analysis 11

D. CLIMATOLOGY 12

1. General 12

2. Method of Analysis 12

E. AIRPORT SELECTION 14

$\begin{array}{ll}\text { III REFERENCES } & 15\end{array}$

Appendix. Tape Record Numbers and Quadrangle Names

Figure 1. Example of Microfiche Listing 2

Table 1. Magnetic Tape Quadrangle Record Format 4 
SECTION I

INTRODUCTION

A. GENERAL

Data essential to effective planning of aerial radiometric surveys for uranium have been identified and compiled by Texas Instruments under Bendix Field Engineering Corporation Project Number 40-78-4129, Subcontract Number 78104-L.

The objective of this study was to present the data in a form readily useful in planning the remainder of the U.S. Department of Energy (DOE) National Uranium Resource Evaluation (NURE) Program National Aerial Radiometric Reconnaissance Survey and to facilitate planning of similar, more detailed, followup surveys in the conterminous United States. The data are presented on microfiche (in pocket) and in digital form on magnetic tape (obtainable from the DOE computer data base).

The National Topographic Map Series (NTMS) quadrangles at 1:250,000 scale were used for survey unit areas in compiling the data. These are identified by name and number as they appear on the topographic maps at that scale. (See USGS, 1976, for an index to the maps.)

The data formats are explained in subsection I.B, and the nature and origin of the planning factors are described in Section II.

\section{B. DATA FORMATS}

1. Microfiche Listings

Figure 1 shows an example of the data listings as they appear on microfiche for each quadrangle.

The Tape Record Number is the Sequence Number (Arbitrary Counter) on the magnetic tape. The latitudes and longitudes of the quadrangle corners are given in decimal degrees (45 7531 means 45.7531 degrees). A cross-reference 1isting of Tape Record Numbers and quadrangle names is in the appendix to this volume. 
NATIONAL AERIAL RADIOMETRIC RECONMAISSANCE SURVEY PLANNing PARAMETERS

QUADRANGLE NAME: GRAND JUNCTION

NTMS NUMBER: NJ12-3

TAPE RECORD NUMBER: 233

$\begin{array}{lllll}\text { S.W. CORNER LATITUDE : } & 390000 & \text { S.W. CORNER LONGITUDE : } & 1100000 \\ \text { N.E. CORNER LATITUDE : } & 400000 & \text { N.E. CORNER LONGITUDE : } & 1080000\end{array}$

GEOLOGIC PRIORITY AND RELATIVE COUNT RATE

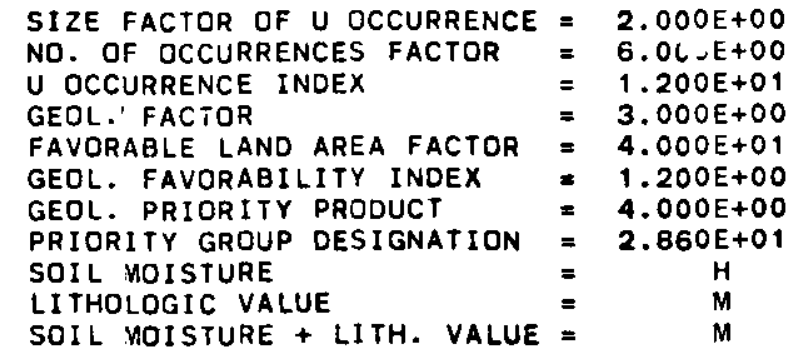

TERRAIN EVALUATION :

$\begin{array}{ll}\text { LAND SURFACE (SQ. MILES) } & =7.374 E+03 \\ \text { PERCENT FIXED-WING } & =1.183 E+01 \\ \text { PERCENT ROTARY-WING } & =8.817 E+01\end{array}$

AIRPORTS :

NAME : GRAND JUNCTION LATITUDE : 390597 LONGITUDE : 1087919

PROJJECTED GOOD WEATHER FLYABLE HOURS PER MONTH :

\begin{tabular}{|c|c|c|c|c|}
\hline $\begin{array}{c}\text { JANUARY } \\
0\end{array}$ & $\begin{array}{c}\text { FEBRUARY } \\
0\end{array}$ & $\begin{array}{l}\text { SEPTEMBER } \\
110\end{array}$ & $\begin{array}{c}\text { OCTOBER } \\
114\end{array}$ & $\begin{array}{c}\text { NOVEMBER } \\
102\end{array}$ \\
\hline
\end{tabular}

WEATHER STATION DATA : STA. LATITUDE : 391167 STA. LONGITUDE : 1085333

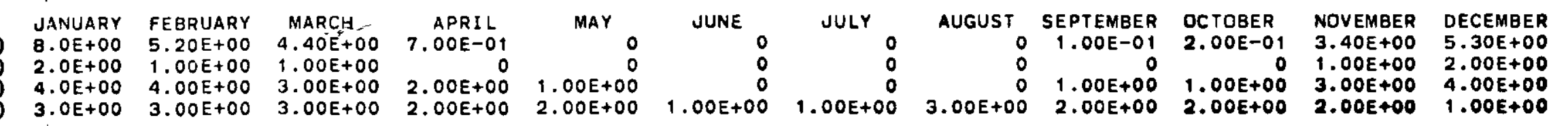

$A=I N C H E S$ OF SNOW.

= NO. OF DAYS WHEN CEILING IS LESS THAN $1500 \mathrm{FT}$. AND VISIBILITY IS LESS THAN 3 MILES.

$G$ - NO. OF DAYS WHEN CEILING IS LESS THAN 5000 FT. AND VISIBILITY IS LESS THAN 5 MILES.

D NO. DF DAYS PRECIPITATION IS LESS THAN 0.1 INCHES.

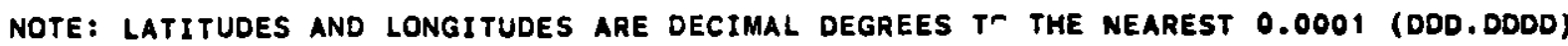

Figure 1. Example of Microfiche Listing 
All non-zero numerical values under Geologic Priority and Relative Count Rate and Terrain Evaluation are given in scientific notation (2.300 E+ 02 means $2.300 \times 10^{2}$ ). These parameters are defined in Section II.

\section{Magnetic Tape}

Data are on a nine-track, 1600-bpi, binary tape having the following record format:

$$
\begin{array}{ll}
\text { RECFM }=\text { FB } & \text { Fixed-length records } \\
\text { LRECL = 480 } & \begin{array}{l}
\text { Logical record length is } 480 \text { bytes } \\
\text { (120 four-byte words) }
\end{array} \\
\text { BLKSIZE = 9600 } & \text { Blocked by 20 }
\end{array}
$$

Table 1 describes each quadrangle record in detail. 
Table 1

Magnetic Tape Quadrangle Record Format.

Word

(Four Bytes Each)

Type*

Description

$1-2$

4-7

$4-7$
$8-9$

10

10
11

12

14-15

16

17

18
19

20

21
22

23

24

26

27-28

29
30

31

32-33

$35-38$

39

40
$41-44$

45
46

47-50

51

53-54

55

56
57

57

.

65

66
$67-68$

69

70

71
$72-75$

$76-79$

$80-83$

84-87

88-91

92-95

96-99

100-103

104-107

108-111

112-115

116-119

120

A

I

I

- <Quad>1 - Quadrangle name and location

Sequence No. (arbitrary counter)

Quadrangle name

NTMS map no.

SW corner latitude**

SW corner longltude**

NE corner latitude**

$\mathrm{NE}$ corner longitude**

'<GEOL>' - geologic priority and relative count rate

Size factor of $U$ occurrence

$U$ occurrence Index

No. of occurrences factor

Priority group designation

Geologic priority product

Geologic factor

Geologic favorability index

Favorable land area factor

Soil molsture (L, L-M, M, M-H, H)

Lithologic value ( $L, L-M, M, M-H, H)$

Soll moisture + lithologic value (L, M, H)

'<TERR>' - terrain evaluation

Land surface (square miles)

\% fixed-wing coverage

$\%$ rotary-wing coverage

' $\angle$ AIR>' - airports

No. of airports this quadrangle (maximun is three)

Name of airport No. 1

Latitude ${ }^{* \star}$

Longl tude $\mathrm{e}^{\star *}$

Name of airport No, 2

Latitude ${ }^{\star \star}$

Longitude**

Name of a1rport No. 3

Latitude ${ }^{\star \star}$

Longitude ${ }^{\star \star}$

'<Hours>' - projected good weather flyable hours per month

No. hours in January

No. hours in February

No. hours in March

No. hours in November

No. hours in December

'<WEATHR>' - weather station data

$=0$ no weather station this quadrangle

$=1$ quadrangle contains weather station

Station latitude ${ }^{\star *}$

Station longitude**

January ${ }^{* \star \star}$ A, B, C, D

February $A, B, C, D$

March A,B, C,D

April A,B,C,D

May $A, B, C, D$

June $A, B, C, D$

July $A, B, C, D$

Augus $t A, B, C, D$

September $A, B, C, D$

October $A, B, C, D$

November $A, B, C, D$

December $A, B, C, D$

Blank

${ }^{*}{ }_{A}=$ alphanumeric, $I=$ integer, $R=$ floating-point real.

** Latitude and longitude are decimal degrees to the nearest 0.0001 (DDD.DDDD).

$\star \star \star \star$

. Inches of snow 1500 feet and visibility less than 3 miles.

C. No. of days when celling less than 5000 feet and visibility less than 5 miles.

D. No. of days precipitation 1s less than 0.1 inch. 


\section{SECTION II}

PLANNING PARAMETERS

\section{A. GEOLOGIC PRIORITY}

1. Genera1

All the 1:250,000-scale quadrangles of the conterminous United States have been rated as to their priority for airborne geophysical surveys based on known uranium occurrences and general geologic favorability for uranium deposits. The underlying philosophy of the rating is that quadrangles should be granted priority if they have been demonstrated to contain mineable deposits and/or geologic outcrops that are likely to contain undiscovered deposits. On the other hand, no quadrangles should be eliminated completely from this type of broad reconnaissance inasmuch as there may be undiscovered occurrences or even new types of deposits not yet comprehended by the known principles of uranium geology. There also may be favorable rock types present in the quadrangles that are not identified separately at the scale of geologic mapping used in the analysis, i.e., the 1:2,500,000-scale geologic map of the United States (King and Beikman, 1974). The source for known uranium occurrences is Butler, Finch, and Twenhofel (1962) supplemented by Texas Instruments (1976) in New England and Texas Instruments (1975) in southeast Arizona.

Sources of information on uranium geology include IAEA (1970, 1973, 1974), and Bowie et al (1972). Grutt (1972) indicated that although vein deposits may provide the highest ore grades, about 95 percent of U.S. production and reserves are accounted for in sedimentary rocks. Finch (1967) showed that approximately 97 percent of these are in sediments of continental origin. About 98 percent of current U.S. production comes from this type of deposit (USERDA, 1975).

Hetland (1975) indicated that according to the preliminary NURE evaluation the possible and speculative future uranium resources in veins and igneous disseminated type deposits may constitute a much larger portion of the total than indicated by past experience. This conclusion is supported by the recent recognition of the Rossing disseminated deposit in southwest Africa as a very significant deposit type (Gableman, 1974), the discovery of very large vein-type uranium reserves in Australia (Wright, 1976), and the suggestion by Lieberman (1976) that 
analysis of historical discovery data indicates that very limited amounts of sandstone-type ores remain to be discovered.

For the purpose of this study it was arbitrarily assumed that twice as many relatively near-term future deposits will be found in continental sediments as will be found in igneous intrusive units considered favorable as sources or hosts for vein or disseminated deposits.

Finch (1967) presents an excellent overall summary of the geology of epigenetic uranium deposits in sandstone. Grutt (1972) and Fischer (1974) provide lists of criteria for prospecting for sandstone deposits and summarize the principal U.S. producing districts. Adler (1974) reviews the concepts of uranium ore formation in the sandstone deposits. Dean (1960) provides a selected annotated bibliography of the geology of uranium-bearing vein deposits, and the USGS (1963) presents a series of papers discussing the geology, mineralogy, structure, age and alteration of these types of deposits. These were all used to provide the background for developing the analytical method used to assign geologic priorities. Saunders and Potts (1978) have summarized recent information on the geochemistry and geologic occurrence of uranium.

\section{Method of Analysis}

An overall numerical priority, the Geological Priority Product (P), was calculated for each quadrangle using a Uranium Occurrence Index (U) and a Geologic Favorability Index $(G)$. Both $U$ and $G$ are products of "intensity" and "extent" factors.

The Uranium Occurrence Index (U) is the product of the Size Factor, i.e., the largest uranium occurrence ("intensity"), and the Number of Occurrences Factor ("extent") in the quadrangle. The size factor was assigned as follows using data from Butler, Finch, and Twenhofel (1962):

\begin{tabular}{cl} 
Size Factor & \multicolumn{1}{c}{ Characteristic } \\
\hline 0 & No known occurrences \\
1 & Occurrence only - no production or reserves known \\
2 & Known production and reserves less than 1000 tons \\
3 & Known production and reserves more than 1000 tons
\end{tabular}


The figures for the Number of Occurrences Factor also are taken from Butler, Finch, and Twenhofel (1962).

The Geological Favorability Index $(G)$ is the product of the Geologic Factor ("intensity") and the Favorable Land Area Factor ("extent"). The Geological Factor is assigned on the following basis using King and Beikman (1974) within the constraints of the legend of that map:

\section{Geological Factor}

0

1

1

2

\section{Characteristic}

No favorable outcrops shown

Continental deposits older than Triassic present Granitic or alkaline igneous intrusive present (includes all $\mathrm{Ti}$ map units)

Continental deposits younger than Permian (includes $J$, $J \mathbb{R}$ and $\mathbb{R}$ units in the Colorado Plateau, the Dockum Group in Texas, the Newark Group in the Appalachian region, and $\mathrm{Te}_{3}$, the Jackson Group, in the Gulf Coast area).

A quadrangle containing both favorable igneous and favorable continental outcrops was assigned the sum of the two factors. The Favorable Land Area Factor was determined by visual estimation of the percentage of the land surface area of the quadrangle covered by favorable outcrops.

The Geological Priority Grade, P, was calculated using the following formula :

$$
P=(U+1)(G+I)
$$

A unit was added to each index prior to multiplying to avoid obtaining zero values. Using this approach, if both $U$ and $G$ are zero, $P$ will be exactly unity, which would represent the lowest Geologic Priority Grade.

The nature of the formula for $\mathrm{P}$ is such that the resulting numbers are quite sensitive to the number of known uranium occurrences present, and values above 100 are common in the quadrangles containing major mining districts. On the other hand, quadrangles without known occurrences but with favorable geological outcrops range only up to 3.0 as a maximum value. 
3. Quadrangle Priority Groups

To simplify integrating the Geologic Priority Grade with the other planning factors, each quadrangle has been assigned to one of three Priority Groups as follows:

Priority
Grade

I

II

III
Geologic Priority Grade

$3.5-460$

$1-3.5$

$=1$
Number of Quads

139

197

132
Recommended Flight Line Spacing

3-1/8 mi $\times 6-1 / 4 \mathrm{mi}$ $6-1 / 4 \mathrm{mi} \times 12-1 / 2 \mathrm{mi}$ $12-1 / 2 \mathrm{mi} \times 25 \mathrm{mi}$

The geographic distribution of quadrangles by priority is roughly in accord with the NURE preliminary estimates of uranium potential by regions (Hetland, 1975). As shown by Malan (1972), the largest block of Priority Group I quadrangles is in agreement with regional patterns of uranium enrichment in Precambrian rocks as well as with his regions of inferred favorability for stratiform uranium deposits.

\section{B. ANTICIPATED RELATIVE COUNTING RATE}

\section{General}

Experience has shown that the statistical quality of airborne gamma-ray spectrometer data as determined by the observed counting rates varies from region tc region depending on lithology and the amounts of water in the soil or vegetation present to absorb the emitted gamma rays.

An index based on these variables has been formulated for estimating the overall relative gamma activity to be expected in each quadrangle.

\section{Method of Analysis}

The USGS National Atlas was used as the basic source of information in classifying quadrangles in terms of average soil moisture and lithology. These two factors were judged qualitatively and independently in terms of low, medium, or high relative counting rates to be expected. The data for each factor were then weighted and summed to provide a numerical index reflecting the contributions of both factors. 
A 1:7,500,000-scale map entitled Distribution of Principal Kinds of Soils in the National Atlas of the United States of America (USGS, 1970, p. 8687) shows all the soil types classified as wet, moist, or dry. These categories were taken as indicating respectively low, medium, and high relative counting rates to be expected due to water absorption of the gamma radiation. In general, the amount of vegetation increases with soil moisture so that the effect of vegetative absorption is included in the factor at least to a first approximation. Each quadrangle was examined to determine the dominant degree of soil wetness as mapped. If the area was split between two of the three major classifications it was assigned an intermediate classification resulting in five levels of wetness:

$\begin{array}{lllll}\text { Relative Gamma Activity } & & \text { Symbol } & \text { Values } \\ \text { Low } & =\mathrm{L} & = & 1 \\ \text { Medium-1ow } & =\mathrm{M}-\mathrm{L} & = & 2 \\ \text { Medium } & =\mathrm{M} & = & 3 \\ \text { High-medium } & =\mathrm{H}-\mathrm{M} & = & 4 \\ \text { High } & =\mathrm{H} & = & 5\end{array}$

The appropriate symbol is recorded for each quadrangle as the soil moisture parameter.

A 1:7,500,000-scale map of the United States entitled Tectonic Features (USGS, 1970, p. 70-71) was used to judge the approximate average counting rates for each quadrangle based on general lithology known or suspected to be present in each tectonic unit. The following listing shows the classification of these units in terms of low, medium, or high expected relative counting rates.

\section{Tectonic Unit Classification}

\begin{tabular}{cl}
$\begin{array}{c}\text { Relative } \\
\text { Gamma Activity }\end{array}$ & \multicolumn{1}{c}{ Tectonic Units } \\
\hline High & $\begin{array}{l}\text { Granitic and other intrusive rocks of Tertiary age } \\
\text { Granitic and other intrusive rncks of Mesozoic age } \\
\text { Granitic rocks of Paleozoic age }\end{array}$ \\
& Metamorphic and plutonic rocks of Precambrian age \\
Medium & P1atform deposits overlying basement rocks \\
& Terrestrial basin fill \\
& Marine deposits \\
& All geosync1inal deposits \\
& All Appalachian post-orogenic deposits \\
& U1tramafic rocks \\
Low & Terrestria1 volcanic rocks \\
& Sedimentary and volcanic rocks of later Precambrian age
\end{tabular}


Each quadrangle was examined to determine the expected dominant relative counting rate in terms of five levels:

\begin{tabular}{|c|c|c|}
\hline $\begin{array}{c}\text { Relative } \\
\text { Gamma Activity }\end{array}$ & Symbol & Values \\
\hline Low & $\mathrm{L}$ & 1 \\
\hline Medium-Low & M-L & 2 \\
\hline Medium & M & 3 \\
\hline High-Medium & $\mathrm{H}-\mathrm{M}$ & 4 \\
\hline High & $\mathrm{H}$ & 5 \\
\hline
\end{tabular}

The appropriate symbol is recorded for each quadrangle as the 1ithologic value.

3. Combined Moisture and Lithology Factors

The soil moisture and lithologic values were then added to obtain the count rate sum as follows:

\begin{tabular}{|c|c|c|}
\hline $\begin{array}{c}\text { Relative } \\
\text { Gamma Activity }\end{array}$ & Symbol & $\underline{\text { Sum }}$ \\
\hline Low & $\mathbf{L}$ & $1-4$ \\
\hline Medium & M & $5-8$ \\
\hline High & $\mathbf{H}$ & $9-10$ \\
\hline
\end{tabular}

Assigned symbols are recorded for each quadrangle.

\section{TERRAIN FACTORS IN AIRCRAFT SELECTION}

1. General

The terrain analysis of the conterminous United States is based 1) on the 1:7,500,000-scale Land-Surface Form map which is part of the National Atlas of the United States of America (pp. 62-64), and 2) on 1:1,000,000-scale photographic reductions of 1:250,000-scale topographic maps. Actual flying experience from NURE surveys flown in the Wind River basin (Texas Instruments, 1974a), the Powder River basin (Texas Instruments, 1974b), southeast Arizona (Texas Instruments, 1975), and New England (Texas Instruments, 1976) has been used to evaluate the mapped classes of land-surface form in terms of suitability for fixedwing data collection. To be judged suitable, 90 percent or more of the records must be expected to fall within the specified 200- to 700-foot terrain clearance 
envelope. Areas found unsuitable on that basis for fixed-wing aircraft have been classified as rotary-wing areas. The results are expressed as percentages of the area of each quadrangle suitable for each type of aircraft.

\section{Method of Analysis}

Every east-west, fixed-wing flight line in the New England area (Texas Instruments, 1976) and every other north-south flight line in the Arizona area (Texas Instruments, 1975) has been examined record-by-record to identify those having terrain clearance within the specified 200- to 700-foot terrain clearance envelope. These data were compared to the corresponding classes of land-surface form, and those with 10 percent or more terrain clearance records outside the specified envelope were judged unsatisfactory for fixed-wing coverage and assigned to rotary-wing aircraft. Certain terrain classes were not covered by actual experience but were judged on the basis of descriptive comparisons with the "calibrated" units. This resulted in classifying the following terrain map units shown on the Land-Surface Form map as rotary-wing areas:

Map Unit

D6

D5

C6a

$\mathrm{c} 6 \mathrm{~b}$

C6c

C5a (selected portions)

B6a

B6b

B6d

\section{Description}

\section{High mountains}

Low mountains

Open high mountains

Open high mountains

open high mountains

Open low mountains

Open high mountains with more than 75 percent of gentle slope in lowland

Open high mountains with $50-75$ percent of gentle slope in lowland

Plains with high mountains

These areas as shown on the Land-Surface Form map were then transferred to $1: 1,000,000$-scale reductions. The topographic information on the 1:1,000,000scale reductions was used to refine the rotary-wing/fixed-wing area boundaries. The rotary-wing areas were enlarged in some regions to eliminate fixed-wing eastwest flight lines shorter than about 40 kilometers and to remove very small fixedwing flight areas. 
D. CLIMATOLOGY

\section{General}

The climatological study encompasses the entire conterminous United States and is based on data supplied by the National Oceanic and Atmospheric Administration, the Environmental Protection Agency, U.S. Naval Weather Service, and the U.S. Weather Service of the Department of Commerce.

The objective of the climatological study is to derive for each quadrangle the following factors:

- Number of suitable flying days per month

- Number of suitable flying hours per day

- Number of suitable flying hours per month

\section{Method of Analysis}

The following ceiling, precipitation, and visibility data from all U.S. weather stations reporting on the upper air conditions in the United States were considered in this study:

- Average number of inches of snowfall per month (from NOAA, 1974)

- Mean number of days per month with ceilings less than 1500 feet and/or visibility less than 3 miles (from U.S. Naval Weather Service)

- Mean number of days per month with ceilings less than 5000 feet and/or visibility less than 5 miles (from USAF-ETAC, various dates)

- Mean number of days per month with total precipitation greater than or equal to 0.1 inch (U.S. Weather Service, 1965)

The number of suitable flying days per month was determined utilizing the above data.

Texas Instruments flying experience in the United States when compared with the climatological data indicates that the mean number of days per month suitable for airborne data collection is equal to the total days in that month minus the mean number of days per month with ceilings less than 5000 feet and/or 
visibility less than 5 miles and minus the mean number of days per month with total precipitation greater than or equal to 0.1 inch.

The mean number of suitable data collection hours per day were derived using actual experience to take into account the occurrence of low-level temperature inversions that would prevent data collection. Inversions, prevalent under calm air conditions, usually will delay data collection until the horizontal wind velocity component creates sufficient vertical mixing to disperse the inversion. Therefore, the probability that inversions will prevent data collection is inversely proportional to the mean wind velocity. Holzworth (1972) presents seasonal morning and afternoon values of mean wind velocity (excluding days with precipitation) for all the upper air weather stations in units of meters per second. The morning and afternoon mean wind velocities were averaged and compared with data collection experience where available. The averaged daylight wind velocities, which vary from 1.1 to 9 meters per second, were found to be numerically equal to the actual suitable data collection flying hours per day within a few percent when compared on a seasonal basis. Thus, the numerical value of mean wind velocity was used as a "rule of thumb" estimate of suitable data collection hours per day. This value multiplied by the mean number of suitable flying days per month produced the average monthly suitable data collection hours (H) for each weather station. Suitable data collection hours for each quadrangle (Hq) by month were determined by combining data from the three closest weather stations using the following equation:

$$
\mathrm{Hq}=\frac{\mathrm{H} 1 / \mathrm{D} 1+\mathrm{H} 2 / \mathrm{D} 2+\mathrm{H} 3 / \mathrm{D} 3}{1 / \mathrm{D} 1+1 / \mathrm{D} 2+1 / \mathrm{D} 3}
$$

where D1 is distance from the center of the quadrangle to weather station 1 , etc., and $\mathrm{Hl}$ is the number of suitable data collection hours for weather station 1 , etc.

Flying experience has shown that, generally, a mean monthly snowfall of 5 inches or greater is sufficient to preclude data collection during that month. All monthly snowfall averages equal to or greater than 5 inches were noted, and the corresponding values of suitable data collection hours per month, Hq, were reduced to zero. 
The final flyable hours per month are provided for each quadrangle as Projected Good Weather Flyable Hours per Month. The ceiling, precipitation, and visibility data from all U.S. weather stations reporting on upper air conditions within each quadrangle are listed under Weather Station Data. A11 non-zero numbers are presented in scientific notation $\left(1.5 \mathrm{E}+02=1.5 \times 10^{2}\right)$.

\section{E. AIRPORT SELECTION}

A list of 1051 airports having suitable facilities for reciprocating engine aircraft of the DC-3 type, adequate transportation, communication facilities, and convenient air-crew accommodations was compiled from the most current Jeppesen Airway Manual and the Aircraft Owners and Pilots Association (AOPA) "Airports USA".

The 1ist was checked against a recent Instrument Flight Rules Supplement of the United States issued by the Department of Defense to confirm the accuracy of the information and to obtain the precise latitude and longitude of each airport.

Finally, a selection was made to provide a relatively uniform density of the best airports available throughout the United States except in the vicinity of major population centers, where many suitable airports are available and a relatively greater density was maintained to allow more flexibility in planning Within each quadrangle, the most suitable airport has been labeled "1," the second most suitable " 2 ," etc.

Rotary-wing operations do not depend on airport facilities, and the flexibility required in day-to-day operation does not allow detailed preplanning. 


\section{SECTION III}

\section{REFERENCES}

Adler, H.H. 1974. Concepts of uranium-ore formation in reducing environments in sandstones and other sediments. Formation of Uranium Ore Deposits. Proceedings Series, International Atomic Energy Agency, Vienna, pp . 141-168.

Bowie, S.H.U., M. David, and D. Ostle. 1972. Uranium Prospecting Handbook, the Institution of Mining and Metallurgy, London, 346 p.

Butler, A.P. Jr., W.I. Finch, and W.S. Twenhofel. 1962. Epigenetic uranium deposits of the United States; Map MR-21, USGS, Washington, D.C.

Dean, B.G. 1960. Selected annotated bibliography of the geology of uraniumbearing veins in the United States; Bull. 1059-G, USGS, Washington, D.C., pp. 327-439.

Finch, W.I. 1967. Geology of epigenetic uranium deposits in sandstone in the United States. Prof. Paper 538, USGS, Washington, D.C., 121 p.

Fischer, R.P. 1974. Exploration guides to new uranium districts and belts. Econ. Geol., V. 60, pp. 362-376.

Gableman, J.W. 1974. Frontiers of uranium exploration; paper presented at AIME meeting, Dallas, Texas, Feb. 25.

Grutt, E.W. Jr. 1972. Prospecting criteria for sandstone-type uranium deposits. In: Uranium Prospecting Handbook (S.H.U. Bowie et a1, eds.), Institute of Mining and Metallurgy, London, pp. 47-78.

Hetland, D.L. 1975. Potential Resources; Uranium Industry Seminar, U.S. Energy Research and Development Admin., Grand Junction, Colo., October, 16 p.

Holzworth, G.C. 1972. Mixing heights, wind speeds, and potential for urban air pollution throughout the contiguous United States. Air Programs Publication No. AP-101; Environmental Protection Agency, Research Triangle Park, North Carolina, $118 \mathrm{p}$.

International Atomic Energy Agency. 1970. Uranium exploration geology. Vienna, $384 \mathrm{p}$.

- 1973. Uranium exploration methods. Vienna,

$320 \mathrm{p}$.

Vienna, $748 \mathrm{p}$.

- 1974. Formation of uranium ore deposits.

King, P.B. and H.M. Beikman. 1974. Geologic map of the United States (exclusive of Alaska and Hawaii); scale 1:2,500,000; USGS, Washington, D.C.

Lieberman, M.A. 1976. United States uranium resources - an analysis of historical data; Science, v. 192, n4328; pp. 431-436. 
Malan, R.C. 1972. Summary Report - Distribution of uranium and thorium in the Precambrian of the western United States, AEC-RD-12 USAEC, Grand Junction, Colo., Fig. 10, p. 41 .

National Oceanic and Atmospheric Administration. 1974. Climates of the states (2 volumes). prepared by officials of the NOAA. published by the Water Information Center Inc., 14 Vanderventer Ave., Port Washington, N.Y. 11050, 975 p.

Saunders, D.F. and M.J. Potts. 1978. Manual for the application of NURE 19741977 aerial gamma-ray spectrometer data: Doc. GJBX-13(78), Bendix Field Engineering Corporation Subcontract No. 76-031-L, Texas Instruments Incorporated; Issued by U.S. Department of Energy, Grand Junction, Colo.

Texas Instruments Incorporated, 1974a. Airborne Geophysical Survey - Wind River Basin area, Wyoming: Doc. GJo-1631-1, U.S. Atomic Energy Commission Contract AT(05-1)-1631, Grand Junction, Colo.

- 1974b. Airborne Geophysical Survey - Powder River Basin area, Wyoming: Doc. GJO-1631-2, U.S. Atomic Energy Commission Contract AT(05-1)-1631, Grand Junction, Colo.

- 1975. Airborne geophysical survey - southeast Arizona; Doc. GJ0-1643, U.S. Energy Research and Development Administration, Contract AT(05-1)-1643, Grand Junction, Colo.

- 1976. Airborne geophysical survey of a portion of New England; U.S. Energy Research and Development Administration Contract Nos. E(05-1)-1666 and E(05-1)-1667; ERDA Serial No. GJ0-1666-1.

U.S. Air Force Environmental Technical Applications Center (Various dates). U.S. Naval Weather Service world-wide airfield sumnaries; compiled by USAF-ETAC; published by U.S. Naval Weather Service; Vol. VIII, U.S.A. (in 8 parts); Available from National Technical Information Center, Springfield, Va. 22161.

U.S. Energy Research and Development Administration. 1975. Statistical data of the uranium industry; GJO-10n, T.S. Energy Resuarch and Development Administration, Grand Junction, Cole.

U.S. Geological Survey. 1963. Geology of uranium-bearing veins in the conterminous United States; Prof. Paper 445-A through G, USGS, Washington, D.C., $146 \mathrm{p}$.

- 1970. The National Atlas of the United States of America. USGS, Washington, D.C.

. 1976. Index to National Topographic Maps - 1:250,000scale series. USGS, Washington, D.C.

U.S. Weather Service. 1965. Climatic summary of the United States, Supplement for 1951 through 1960 (published by state). Weather Service, U.S. Department of Commerce, Washington, D.C.

Wright, R.J. 1976. Foreign uranium developments: In: Uranium Industry Seminar, Doc. GJO-108(76), v. 2, U.S. Department of Energy, Grand Junction, Colo., p. 309-337. 
APPENDIX

TAPE RECORD NUMBERS AND QUADRANGLE NAMES 


\begin{tabular}{|c|c|c|c|}
\hline Number & Quadrangle Name & Number & Quadrangle Name \\
\hline 1 & Kenora & 54 & Jamestown \\
\hline 2 & Cape Flattery & 55 & Fargo \\
\hline 3 & Victoria & 56 & Brainerd \\
\hline 4 & Concrete & 57 & Duluth \\
\hline 5 & Okanogan & 58 & Ashland \\
\hline 6 & Sandpoint & 59 & Iron River \\
\hline 7 & Kalispel1 & 60 & Marquette \\
\hline 8 & Cut Bank & 61 & Sault St. Marie \\
\hline 9 & Shelby & 62 & Blind River \\
\hline 10 & Havre & 63 & Quebec \\
\hline 11 & Glasgow & 64 & Presque Isle \\
\hline 12 & Wolf Point & 65 & Woodstock \\
\hline 13 & Williston & 66 & Vancouver \\
\hline 14 & Minot & 67 & The Dalles \\
\hline 15 & Devils Lake & 68 & Pendleton \\
\hline 16 & Thief R. Falls & 69 & Grangeville \\
\hline 17 & Roseau & 70 & E1k City \\
\hline 18 & International Falls & 71 & Dillon \\
\hline 19 & Quetico & 72 & Bozeman \\
\hline 20 & Thunder Bay & 73 & Billings \\
\hline 21 & Copalis Beach & 74 & Hardin \\
\hline 22 & Seattle & 75 & Ekalaka \\
\hline 23 & Wenatchee & 76 & Lemmon \\
\hline 24 & Ritzville & 77 & McIntosh \\
\hline 25 & Spokane & 78 & Aberdeen \\
\hline 26 & Wallace & 79 & Milbank \\
\hline 27 & Choteau & 80 & St. Cloud \\
\hline 28 & Great Falls & 81 & Stillwater \\
\hline 29 & Lewis town & 82 & Rice Lake \\
\hline 30 & Jordan & 83 & Iron Mountain \\
\hline 31 & Glendive & 84 & Escanaba \\
\hline 32 & Watford City & 85 & Cheboygan \\
\hline 33 & McClusky & 86 & Alpena \\
\hline 34 & New Rockford & 87 & Sherbrooke \\
\hline 35 & Grand Forks & 88 & Millinocket \\
\hline 36 & Bemidji & 89 & Fredericton \\
\hline 37 & Hibbing & 90 & Salem \\
\hline 38 & Two Harbors & 91 & Bend \\
\hline 39 & Hancock & 92 & Canyon City \\
\hline 40 & Edmundston & 93 & Baker \\
\hline 41 & Campbellton & 94 & Challis \\
\hline 42 & Hoquiam & 95 & Dubois \\
\hline 43 & Yakima & 96 & Ashton \\
\hline 44 & Walla Walla & 97 & Cody \\
\hline 45 & Pullman & 98 & Sheridan \\
\hline 46 & Hamilton & 99 & Gillette \\
\hline 47 & Butte & 100 & Rapid City \\
\hline 48 & W. Sulphur Springs & 101 & Pierre \\
\hline 49 & Roundup & 102 & Huron \\
\hline 50 & Forsyth & 103 & Watertown \\
\hline 51 & Miles City & 104 & New U1m \\
\hline 52 & Dickinson & 105 & St. Pau1 \\
\hline 53 & Bismarck & & \\
\hline
\end{tabular}




\begin{tabular}{|c|c|c|c|}
\hline Number & Quadrangle Name & Number & Quadrangle Name \\
\hline 106 & Eau Claire & 156 & Valentine \\
\hline 107 & Green Bay & 157 & $0^{\prime} \mathrm{Neill}$ \\
\hline 108 & Manitowoc & 158 & Sioux City \\
\hline 109 & Traverse City & 159 & Ft. Dodge \\
\hline 110 & Tawas City & 160 & Waterloo \\
\hline 111 & Kingston & 161 & Dubuque \\
\hline 112 & Ogdensburg & 162 & Rockford \\
\hline 113 & Lake Champlain & 163 & Racine \\
\hline 114 & Lewiston & 164 & Grand Rapids \\
\hline 115 & Bangor & 165 & Detroit \\
\hline 116 & Eastport & 166 & Erie \\
\hline 117 & Coos Bay & 167 & Buffalo \\
\hline 118 & Roseburg & 168 & Elmira \\
\hline 119 & Crescent & 169 & Binghamton \\
\hline 120 & Burns & 170 & Albany \\
\hline 121 & Boise & 171 & Boston \\
\hline 122 & Hailey & 172 & Eureka \\
\hline 123 & Idaho Falls & 173 & Weed \\
\hline 124 & Driggs & 174 & Alturas \\
\hline 125 & Thermopolis & 175 & Vya \\
\hline 126 & Arminto & 176 & McDermitt \\
\hline 127 & Newcastle & 177 & Wells \\
\hline 128 & Hot Springs & 178 & Brigham City \\
\hline 129 & Martin & 179 & Ogden \\
\hline 130 & Mitche11 & 180 & Rock Springs \\
\hline 131 & Sioux Falls & 181 & Rawlins \\
\hline 132 & Fairmont & 182 & Cheyenne \\
\hline 133 & Mason City & 183 & Scottsbluff \\
\hline 134 & La Crosse & 184 & North Platte \\
\hline 135 & Madison & 185 & Broken Bow \\
\hline 136 & Milwaukee & 186 & Fremont \\
\hline 137 & Midland & 187 & Omaha \\
\hline 138 & Flint & 188 & Des Moines \\
\hline 139 & Toronto & 189 & Davenport \\
\hline 140 & Rochester & 190 & Aurora \\
\hline 141 & Utica & 191 & Chicago \\
\hline 142 & Glens Falls & 192 & Ft. Wayne \\
\hline 143 & Portland & 193 & Toledo \\
\hline 144 & Bath & 194 & Cleveland \\
\hline 145 & Medford & 195 & Warren \\
\hline 146 & Klamath Falls & 196 & Williamsport \\
\hline 147 & Adel & 197 & Scranton \\
\hline 148 & Jordan Valley & 198 & Hartford \\
\hline 149 & Twin Falls & 199 & Providence \\
\hline 150 & Pocatello & 200 & Redding \\
\hline 151 & Preston & 201 & Susanville \\
\hline 152 & Lander & 202 & Lovelock \\
\hline 153 & Casper & 203 & Winnemucca \\
\hline 154 & Torrington & 204 & Elko \\
\hline 155 & Alliance & 205 & Tooele \\
\hline
\end{tabular}


Number

206

207

208

209

210

211

212

213

214

215

216

217

218

219

220

221

222

223

224

225

226

227

228

229

230

231

232

233

234

235

236

237

238

239

240

241

242

243

244

245

246

247

248

249

250

251

252

253

254

255
Quadrangle Name

Salt Lake City

Vernal

Craig

Greeley

Sterling

McCook

Grand Island

Lincoln

Nebraska City

Centerville

Burlington

Peoria

Danville

Muncie

Marion

Canton

Pittsburgh

Harrisburg

Newark

New York

Ukiah

Chico

Reno

Millett

Ely

Delta

Price

Grand Junction

Leadville

Denver

Limon

Goodland

Beloit

Manhattan

Kansas City

Mober1y

Quincy

Decatur

Indianapolis

Cincinnati

Columbus

Clarksburg

Cumberland

Baltimore

Wilmington

Santa Rosa

Sacramento

Walker Lake

Tonopah

Lund
Number

256

257

258

259

260

261

262

263

264

265

266

267

268

269

270

271

272

273

274

275

276

277

278

279

280

281

282

283

284

285

286

287

288

289

290

291

292

293

294

295

296

297

298

299

300

301

302

303

304

305
Quadrangle Name

Richfield

Salina

Moab

Montrose

Pueblo

Lamar

Scott City

Great Bend

Hutchinson

Lawrence

Jefferson City

St. Louis

Belleville

Vincennes

Louisville

Huntington

Charleston

Charlottesville

Washington

Salisbury

San Francisco

San Jose

Mariposa

Goldfield

Caliente

Cedar City

Escalante

Cortez

Durango

Trinidad

La Junta

Dodge City

Pratt

Wichita

Joplin

Springfield

Rolla

Paducah

Evansville

Winchester

Jenkins

Bluefield

Roanoke

Richmond

Eastville

Santa Cruz

Fresno

Death Valley

Las Vegas

Grand Canyon 
Number

306

307

308

309

310

311

312

313

314

315

316

317

318

319

320

321

322

323

324

325

326

327

328

329

330

331

332

333

334

335

336

337

338

339

340

341

342

343

344

345

346

347

348

349

350

351

352

353

354

355

356
Quadrangle Name

Marble Canyon

Shiprock

Aztec

Raton

Dalhart

Perryton

Woodward

Enid

Tulsa

Harrison

Poplar Bluff

Dyersburg

Nashville

Corbin

Johnson City

Winston-Salem

Greensboro

Norfolk

San Luis Obispo

Bakersfield

Trona

Kingman

Williams

Flagstaff

Gallup

Albuquerque

Santa $\mathrm{Fe}$

Tucumcari

Amarillo

clinton

Oklahoma City

Ft. Smith

Russellville

Memphis

Blytheville

Columbia

Chat tanooga

Knoxville

Charlotte

Raleigh

Rocky Mount

Manteo

Santa Maria

Los Angeles

San Bernardino

Needles

Prescott

Holbrook

St. Johns

Socorro

Ft. Sumner
Number

Quadrangle Name

357

358

359

360

361

362

363

364

365

366

367

368

369

370

371

372

373

374

375

376

377

378

379

380

381

382

383

384

385

386

387

388

389

390

391

392

393

394

395

396

397

398

399

400

401

402

403

404

405

406

407
Clovis

Plainview

Lawton

Ardmore

McAlester

Little Rock

Helena

Tupelo

Gadsden

Rome

Greenville

Spartanburg

Florence

Beaufort

Long Beach

Santa Ana

Salton Sea

Phoenix

Mesa

Clifton

Tularosa

Roswe11

Brownfield

Lubbock

Wichita Falls

Sherman

Texarkana

E1 Dorado

Greenwood

West Point

Birmingham

Atlanta

Athens

Augusta

Georgetown

San Diego

E1 Centro

Ajo

Tucson

Silver City

Las Cruces

Carlsbad

Hobbs

Big Spring

Abilene

Dallas

Tyler

Shreveport

Jackson

Meridian

Montgomery 


\begin{tabular}{|c|c|c|c|}
\hline Number & Quadrangle Name & Number & Quadrangle Name \\
\hline 408 & Phenix City & 459 & Orlando \\
\hline 409 & Macon & 460 & Laredo \\
\hline 410 & Savannah & 461 & Corpus Christi \\
\hline 411 & James Island & 462 & Tampa \\
\hline 412 & Lukeville & 463 & Ft. Pierce \\
\hline 413 & Nogales & 464 & McAllen \\
\hline 414 & Douglas & 465 & Brownsville \\
\hline 415 & El Paso & 466 & West Palm Beach \\
\hline 416 & Van Horn & 467 & Miami \\
\hline 417 & Pecos & 468 & Key West \\
\hline 418 & San Angelo & & \\
\hline 419 & Brownwood & & \\
\hline 420 & Waco & & \\
\hline 421 & Palestine & & \\
\hline 422 & Alexandria & & \\
\hline 423 & Natchez & & \\
\hline 424 & Hattiesburg & & \\
\hline 425 & Andalusia & & \\
\hline 426 & Dothan & & \\
\hline 427 & Waycross & & \\
\hline 428 & Brunswick & & \\
\hline 429 & Marfa & & \\
\hline 430 & Ft. Stockton & & \\
\hline 431 & Sonora & & " \\
\hline 432 & Llano & & \\
\hline 433 & Austin & & \\
\hline 434 & Beaumont & & \\
\hline 435 & Lake Charles & & \\
\hline 436 & Baton Rouge & & \\
\hline 437 & Mobile & & \\
\hline 438 & Pensacola & & \\
\hline 439 & Tallahassee & & \\
\hline 440 & Valdosta & & \\
\hline 441 & Jacksonville & & \\
\hline 442 & Presidio & & \\
\hline 443 & Emory Peak & & \\
\hline 444 & Del Rio & & \\
\hline 445 & San Antonio & & \\
\hline 446 & Seguin & & \\
\hline $\begin{array}{l}447 \\
448\end{array}$ & $\begin{array}{l}\text { Houston } \\
\text { Port Arthur }\end{array}$ & & \\
\hline 449 & New Orleans & & \\
\hline 450 & Breton Sound & & \\
\hline 451 & Apalachicola & & \\
\hline 452 & Gainesville & & \\
\hline 453 & Daytona Beach & & \\
\hline 454 & Eagle Pass & & \\
\hline 455 & Crystal City & & \\
\hline 456 & Beeville & & \\
\hline 457 & Bay City & & \\
\hline 458 & Plant City & & \\
\hline
\end{tabular}



